P-ISSN 2580 - 7781

E-ISSN 2615 - 3238

\title{
MELEMAHNYA EKONOMI PADA SEKTOR PARIWISATA: DAMPAK DARI PANDEMI COVID-19 DI DESA KUALA INDAH
}

\section{THE WEAKNESS OF THE TOURISM SECTOR: THE IMPACT OF THE COVID-19 PANDEMIC IN KUALA INDAH VILLAGE}

\author{
Diovanni Abdillah ${ }^{1)}$, Fadhillah Isnaini ${ }^{2)}$, Leny Sutiara ${ }^{3)}$, Sabrina Simbolon ${ }^{4)}$, Tantri \\ Rada $^{5}$, Zainarti ${ }^{6}$ \\ 1,2,3,4,5,6 Universitas Islam Negeri Sumatera Utara Medan \\ ${ }^{1}$ Email : diovanniabdillah@gmail.com
}

\begin{abstract}
ABSTRAK
Sejak awal tahun 2020 dunia digemparkan oleh kehadiran wabah virus Covid-19. Di Indonesia sendiri virus Covid-19 menyebar mulai dari awal Maret 2020. Industri pariwisata Indonesia menghadapi berbagai masalah, tantangan dan hambatan di tingkat global maupun nasional. Seperti halnya di Desa Kuala Indah yang merupakan salah satu desa yang memiliki destinasi pariwisata yaitu Wisata Alam Datuk. Wisata Alam Datuk adalah sebuah pantai yang terletak di Desa Kuala Indah, Kecamatan Sei Suka, Kabupaten Batubara. Penelitian ini dilaksanakan pada bulan Agustus 2021, tepatnya di Desa Kuala Indah, Kecamatan Sei Suka, Kabupaten Batubara. Metode penelitian ini adalah pendekatan kualitatif, dengan teknik analisis data yaitu deskripsi kualitatif melalui beberapa teknik pengambilan data berupa wawancara, observasi dan dokumentasi. Adanya Covid-19 ini sangat mempengaruhi sektor Wisata Alam Datuk yang berdampak pada lintas pelaku ekonomi. Seperti berdagang di lokasi Wisata Alam Datuk yang dalam hal ini seharusnya dapat membantu kegiatan ekonomi masyarakat Kuala Indah melalui sektor pariwisatanya. Namun para pedagang diharuskan untuk menutup usahanya dan pengelola pariwisata harus mengurangi skema gaji para karyawannya dalam masa pandemi ini. Dengan adanya beberapa kebijakan dari pemerintah seperti new normal dan kebijakan lainnya yang diterapkan dan diharapkan dapat menstabilkan keadaan ekonomi kembali.
\end{abstract}

Kata kunci: Covid-19, Pariwisata wisata alam datuk

\begin{abstract}
Since the beginning of 2020 the world has been shaken by the presence of the Covid-19 virus outbreak. In Indonesia, the Covid-19 virus has spread since early March 2020. The Indonesian tourism industry faces various problems, challenges and obstacles at the global and national levels. As is the case in Kuala Indah Village which is one of the villages that has a tourism destination, namely Wisata Alam Datuk. Wisata Alam Datuk is a beach located in Kuala Indah Village, Sei Suka District, Batubara Regency. This research was carried out in August 2021, precisely in Kuala Indah Village, Sei Suka District, Batubara Regency. This research method is a qualitative approach, with data analysis techniques, namely qualitative descriptions through several data collection techniques in the form of interviews, observations and documentation. The existence of this Covid-19 greatly affects the Wisata Alam Datuk sector which has an impact on crosseconomic actors. Such as trading at the Wisata Alam Datuk location which in this case should be able to help the economic activities of the Kuala Indah community
\end{abstract}


P-ISSN 2580 - 7781

E-ISSN 2615 - 3238

through its tourism sector. However, traders are required to close their businesses and tourism managers must reduce the salary scheme of their employees during this pandemic. With the existence of several policies from the government such as the new normal and other policies that are implemented and are expected to stabilize the economic situation again.

Keywords: Tourism, Covid-19, Datuk nature tourism

\section{PENDAHULUAN}

Sejak awal tahun 2020 dunia digemparkan oleh kehadiran wabah virus Covid-19. Virus ini berasal dari Wuhan, China. Virus Covid-19 ini merupakan virus yang menular.Virus Corona atau Severe Acute Respiratory 2 (Sars-Cov2) adalah virus yang menyerang sistem pernafasan, sesak nafas, infeksi paru-paru, hingga dapat merenggut nyawa orang yang terinfeksi. Di Indonesia sendiri virus Covid-19 menyebar mulai dari awal Maret 2020 (Susilo et.al., 2020). Wabah virus Covid-19 membuat banyak negara ketakutan mengaduk pikiran dan perasaan sejak kasus Wuhan yang begitu meningkat (Abbas, 2020). Covid-19 merupakan musuh utama manusia dan mengkhawatirkan dunia karena dapat merenggut nyawa banyak manusia. Akibat dari pandemi Covid-19 yang berlangsung selama beberapa bulan ini, menyebabkan melemahnya aktivitas perekonomian.

Aktivitas ekonomi meliputi kegiatan produksi, distribusi, dan konsumsi (Yuniarti et.al., 2020). Produksi adalah kegiatan untuk memproses barang dan jasa yang menciptakan kegunaan. Tujuannya untuk memenuhi kebutuhan manusia termasuk kegiatan untuk menciptakan dan menambah kegunaan (Maulidiyah et.al., 2020).

Berbagai aktivitas perekonomian mulai dari sektor pariwisata hingga perdagangan terpaksa harus menutup usahanya dan memberhentikan para karyawannya. Hal ini juga mendukung peraturan pemerintah untuk menerapkan social distancing. Cara ini tentu memberi dampak langsung terhadap perekonomian bangsa, karena akan banyak pengurangan aktivitas bekerja di luar rumah. Misalnya, berbagai pusat perbelanjaan memutuskan untuk menutup sementara operasionalnya, sehingga pendapatan otomatis menurun. Sejumlah hotel di daerah-daerah wisata seperti Bali, Jakarta, Yogyakarta dan Surabaya ditutup. Pemutusan hubungan kerja (PHK) menjadi langkah efektif bagi 
P-ISSN $2580-7781$

E-ISSN 2615 - 3238

perusahaan untuk mengurangi kerugian perusahaan yang semakin bertambah (Syaharuddin, 2020).

Hal dilakukan untuk meminimalisir rantai penyebaran wabah virus Covid19. Padahal aktivitas ekonomi adalah salah satu bentuk upaya manusia dalam konteks pemenuhannya kebutuhan. Karena keberadaan manusia tidak dapat dipisahkan dari sifat alami untuk berusaha mempertahankan dan menjaga kelangsungan hidup. Seringkali pengukuran kesejahteraan hidup manusia diukur dengan standar kepuasan ekonomi yang dapat dicapai melalui kegiatan ekonomi terkandung dalam kegiatan produksi, distribusi, dan konsumsi. Aktivitas ekonomi yang umumnya dilibatkan oleh masyarakat termasuk pertanian, nonpertanian, dan perdagangan layanan, dan layanan (Abbas, 2020). Kegiatan konsumsi memiliki tujuan memenuhi kebutuhan hidup termasuk untuk memenuhi kebutuhan jasmani dan rohani terpaksa harus dihentikan (Yuniarti et.al., 2020).

Indonesia adalah negara kepulauan yang begitu kaya, indah dan menakjubkan. Kondisi alam seperti letak dan kondisi geografis, lapisan tanah yang subur dan panorama yang indah, serta berbagai flora dan fauna yang kaya akan kandungan darat dan laut. Keindahan dan keunikan alam ini merupakan salah satu peluang Indonesia untuk mengembangkan potensinya, khususnya di bidang pariwisata.

Industri pariwisata Indonesia menghadapi berbagai masalah, tantangan dan hambatan di tingkat global maupun nasional. Selain itu, pergeseran paradigma pariwisata perlu dilihat dalam konteks pembangunan nasional. Pariwisata tidak lagi hanya dilihat sebagai sarana untuk meningkatkan pendapatan nasional, tetapi memiliki cakupan yang lebih luas dan mendasar.

Oleh karena itu, pengembangan industri pariwisata Indonesia perlu lebih terarah dan mampu menempatkan destinasi wisatanya sesuai dengan potensi alam, budaya dan masyarakat yang terdapat di masing-masing daerah. Pembangunan kepariwisataan di Indonesia adalah pembangunan kepariwisataan, sebagai bagian dari upaya pembangunan dan pembangunan, serta kesejahteraan masyarakat dan bangsa. 
P-ISSN 2580 - 7781

E-ISSN 2615 - 3238

Desa Kuala Indah merupakan salah satu desa yang memiliki destinasi pariwisata yaitu Wisata Alam Datuk. Wisata Alam Datuk adalah sebuah pantai yang terletak di Desa Kuala Indah, Kecamatan Sei Suka, Kabupaten Batubara. Destinasi Wisata Alam Datuk dikelola oleh desa atau kecamatan Kuala Indah dibantu oleh Dinas Pariwisata Kabupaten Batubara. Masyarakat Desa Kuala Indah juga ikut mengatur perjalanan menuju Wisata Alam Datuk. Kawasan seluas 3 hektar ini, kini menjadi salah satu destinasi objek wisata pilihan masyarakat, sahabat, tamu maupun warga Batubara.

Pandemi Covid-19 telah menyebabkan gangguan rantai pasokan global dan domestik, fluktuasi pasar keuangan, guncangan permintaan konsumen, dan dampak negatif terhadap industry (Isbaniah et.al., 2020). Seperti pariwisata, tidak dapat dipungkiri bahwa dampak dari wabah Covid-19 akan terasa di seluruh rantai nilai pariwisata. UKM diperkirakan akan sangat terpengaruh. Pandemi Covid-19 telah berdampak pada masyarakat, ekonomi, dan kesejahteraan masyarakat. Dalam hal ini, salah satu sektor yang paling terkena dampak pandemi global ini adalah sektor jasa pariwisata. Salah satu kawasan wisata yang merasakan dampak pandemi Covid-19 di Indonesia adalah di Wisata Alam Datuk, Desa Kuala Indah, Kabupaten Batubara yang sejak lama memiliki daya tarik tersendiri dalam menarik wisatawan. Suasana pantai yang menyegarkan menjadi tujuan utama para wisatawan menghabiskan akhir pekan bersama keluarga.

\section{METODE PENELITIAN}

Penelitian ini dilaksanakan pada bulan Agustus 2021, tepatnya di Desa Kuala Indah, Kecamatan Sei Suka, Kabupaten Batubara. Metode penelitian ini adalah penelitian kualitatif, dengan teknik analisis data deskripsi kualitatif melalui beberapa teknik pengambilan data berupa wawancara, observasi dan studi dokumentasi. Jenis penelitian ini menggunakan penelitian kualitatif dengan menggunakan wawancara dan survei lapangan secara langsung. Metode sendiri merupakan proses, prinsip dan prosedur yang kita gunakan untuk memecahkan masalah dan mencari jawaban.

Penggunaan metode penelitian dimaksudkan sebagai alat utama, dikombinasikan dengan teknik pengumpulan data, analisis data bersifat induktif, 
P-ISSN 2580 - 7781

E-ISSN 2615 - 3238

dan hasil penelitian kualitatif menggunakan peneliti sebagai alat utama kualitasnya, bukan mengubahnya menjadi entitas kuantitatif. Analisis data deskriptif kualitatif digunakan untuk menganalisis, menggambarkan, dan meringkas berbagai kondisi, situasi dari berbagai data yang dikumpulkan berupa hasil wawancara atau pengamatan mengenai masalah yang diteliti yang terjadi di lapangan.

\section{HASIL PENELITIAN DAN PEMBAHASAN}

Peranan sektor pariwisata nasional semakin penting dilihat dari perkembangan dan kontribusi yang diberikan sektor pariwisata melalui penerimaan devisa, pendapatan daerah, pengembangan wilayah, maupun dalam penyerapan sektor pariwisata. Pertama, sektor pariwisata sebagai penghasil devisa untuk memperoleh barang modal yang dipakai dalam proses produksi. Kedua, pengembangan pariwisata menstimulus pembangunan infrastruktur. Ketiga, pengembangan sektor pariwisata mendorong perkembangan sektor-sektor ekonomi lainnya. Keempat, pariwisata ikut berkontribusi terhadap peningkatan kesempatan kerja dan pendapatan. Kelima, pariwisata dapat menyebabkan Active economies of scale (Sholahuddin, 2007).

Dampak Covid-19 sangat berpengaruh besar dalam berbagai sektor, salah satunya bagi pelaku dan usaha pariwisata. Berbagai macam wisata di Indonesia ditutup akibat Covid-19 ini. Salah satu provinsi di Indonesia yang memiliki objek wisata yang banyak dikunjungi oleh wisatawan yaitu Sumatera Utara. Sumatera Utara memiliki banyak objek pariwisata untuk dikunjungi, salah satunya Wisata Alam Datuk Batu Bara. Wisata Alam Datuk merupakan sebuah pantai yang terletak di Desa Kuala Indah, Kecamatan Sei Suka, Kabupaten Batubara. Wisata Alam Datuk adalah salah satu tempat wisata yang terpengaruh oleh adanya Covid19 tersebut. Wisata Alam Datuk ini menyediakan spot foto yang unik dan indah. Selain disuguhkan oleh sejuknya angin dan hijaunya pohon waru, juga disuguhkan rumah pohon sehingga banyak wisatawan yang tertarik untuk berkunjung, namun karena adanya pandemi maka dilakukan penutupan sementara dan kemudian dibuka kembali pada masa new normal. 


\section{P-ISSN 2580 - 7781}

E-ISSN 2615 - 3238

Berdasarkan hasil wawancara yang dilakukan dalam penelitian ini bersama dengan pengelola Wisata Alam Datuk. Diketahui bahwa Wisata Alam Datuk Batu Bara pertama kali dibuka pada tanggal 28 Desember 2008, sedangkan dikenal publik pada tahun 2010 sampai dengan sekarang ini. Obyek wisata Pantai Alam Datuk dikelola oleh desa atau kelurahan Kuala Indah dibantu oleh Dinas Kepariwisataan Kabupaten Batubara. Masyarakat di desa Kuala Indah juga turut bergotong royong untuk mengelola wisata Pantai Alam Datuk ini. Area seluas 3 hektar ini kini menjadi salah satu destinasi objek wisata pilihan masyarakat, sahabat, tamu maupun warga Batubara.
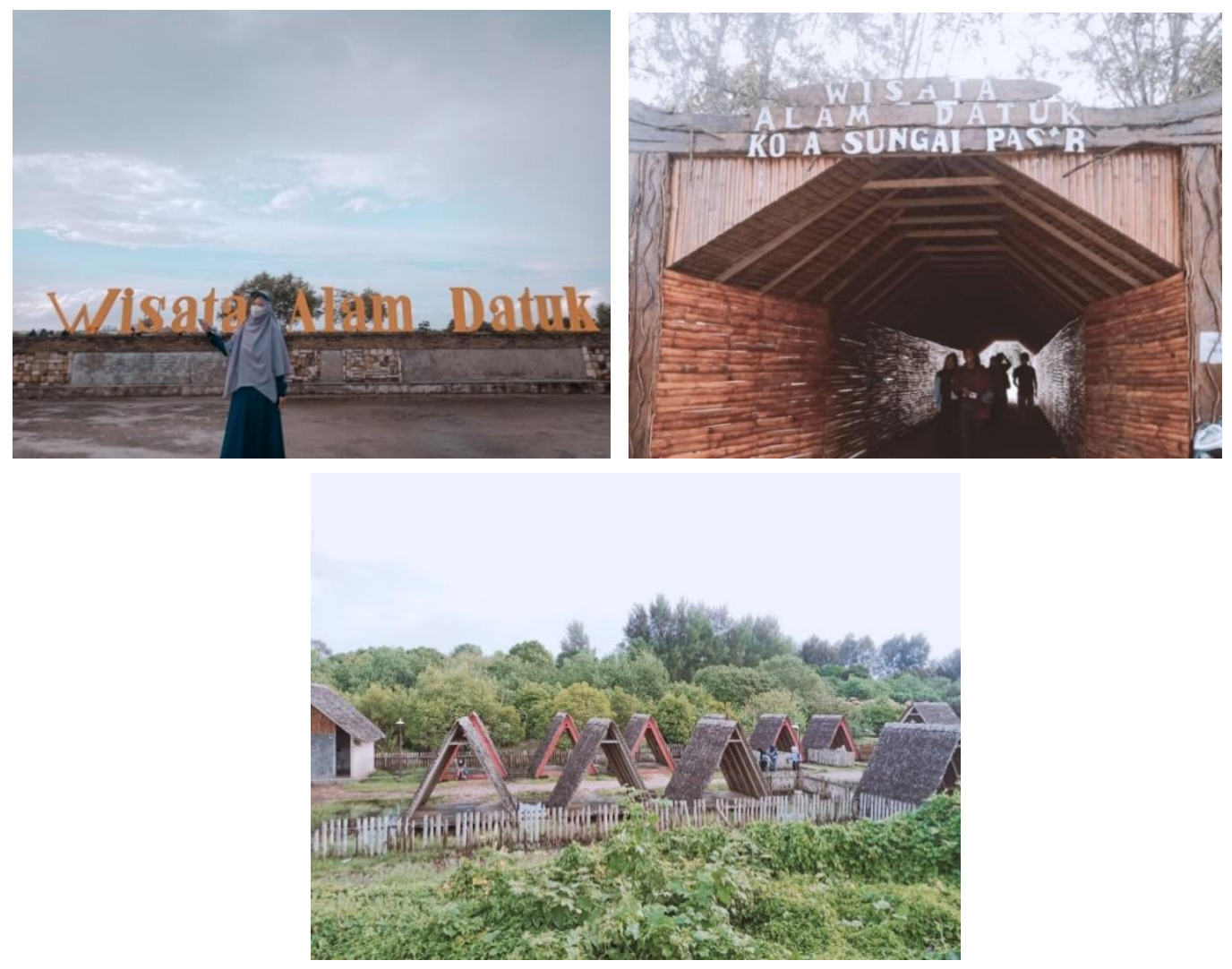

Gambar 1. Spot Foto Wisata Alam Datuk.

Untuk mencapai objek wisata Pantai Alam Datuk tidaklah sulit. Ada tiga pintu masuk yang bisa dilalui, jika dari Kota Medan bisa masuk dari Simpang Kuala Tanjung, Simpang Empat Limapuluh dan Simpang Sei Bejangkar. Jika mengendarai bus atau mobil kurang lebih sejauh $20 \mathrm{~km}$ atau 30 menit perjalanan melintasi areal perkebunan dan hamparan sawah yang membentang luas. Tiket 
P-ISSN $2580-7781$

E-ISSN 2615 - 3238

masuk objek wisata Pantai Alam Datuk terbilang cukup murah, karena pengunjung hanya cukup membayar sebesar Rp10.000/orang pada hari biasa. Sedangkan tiket masuk ke pantai alam datuk pada weekend atau akhir pekan adalah sebesar Rp 15.000 tiket ini sudah termasuk tiket parkir sehingga pengunjung tidak perlu lagi membayar parkir. Perjalanan menuju wisata Pantai Alam Datuk dapat melalui Jalan acces road Inalum kemudian masuk ke Jalan Kuala Indah dan tidak lama kemudian akan sampai ke lokasi wisata Pantai Alam Datuk.

Strategi yang dilakukan pengelola Wisata Alam Datuk dalam menarik pengunjung yaitu dilakukan dengan berbagai cara. Pada tahun 2010, saat Wisata Alam Datuk sudah mulai dikenal oleh publik, dilakukan dengan cara mempromosikan Wisata Alam Datuk menggunakan media cetak yaitu brosur, spanduk, dan media elektronik yaitu radio. Kemudian, seiring berkembangnya zaman dan teknologi, pada tahun 2016 promosi dilakukan menggunakan media sosial seperti Instagram, Facebook, Tiktok dan lain sebagainya.

Adanya obyek wisata yang beroperasi pada tahun 2010 di Wisata Alam Datuk, mengalami pasang surut untuk jumlah pengunjung baik dari luar kota maupun dalam kota. Jumlah pengunjung Wisata Alam Datuk meningkat pada tahun 2018 dimana pada tahun sebelumnya jumlahnya 3000 pengunjung, dan meningkat pada tahun 2018 menjadi 8000 pengunjung. Tetapi dibalik peningkatan tersebut, banyak usaha atau strategi yang dilakukan oleh pihak pengelola seperti mengadakan kegiatan pembagian brosur, spanduk, promosi lewat media sosial dari tahun 2011 hingga tahun 2018.

Namun hal ini tidak berlangsung lama karena pada tahun 2020, Covid-19 mulai melanda Indonesia yang bukan hanya berpengaruh terhadap kesehatan masyarakat Indonesia, tetapi juga berpengaruh terhadap perekonomian masyarakat Indonesia terutama pada sektor pariwisata (Purwahita et.al., 2021). Karena ketika masa pandemi Covid-19 mulai melanda Indonesia, tempat wisata mulai ditutup terutama destinasi Wisata Alam Datuk ini. Meskipun di masa new normal kembali dibuka tetapi jumlah pengunjung berkurang, terutama pengunjung yang berasal dari luar kota. 
P-ISSN 2580 - 7781

E-ISSN 2615 - 3238

Pada awal pandemi Covid-19, jumlah pengunjung atau wisatawan sangat berpengaruh terhadap Wisata Alam Datuk. Jumlah kunjungan berkurang drastis kira-kira 90\%. Tetapi saat sudah memasuki new normal, jumlah wisatawan meningkat dari sebelumnya, salah satu alasannya karena orang-orang sudah mulai bosan dirumah saja saat masa pandemi Covid-19. Selain itu, adanya Covid-19 ini juga menimbulkan suatu pertimbangan bagi pengelola dalam memberi gaji pihak karyawan. Apakah harus dilakukannya pemecatan atau pemberhentian karyawan atau hanya pengurangan skema gaji karyawan saja. Berdasarkan hasil wawancara dengan pengelola Wisata Alam Datuk, bahwasanya keputusan yang diambil yaitu hanya melakukan pengurangan gaji karyawan saja.

Adapun pendapat Pak Arfian selaku pengelola Wisata Alam Datuk menyatakan bahwa:

"Awalnya kami berfikir ingin memberhentikan karyawan, tetapi setelah kami fikirkan lebih lanjut dan berkomunikasi dengan karyawan yaitu cukup dengan mengubah skema gaji tanpa dilakukannya pemberhentian atau pengurangan pihak karyawan, dan alhamdulillah mereka paham akan situasi dan kondisi saat ini"'.

Selain berbicara mengenai gaji karyawan, Pak Arfian selaku pengelola Wisata Alam Datuk juga mengatakan bahwasanya:

"Pada masa pandemi pendapatan kami hanya 40\%, pendapatan tersebut merupakan pendapatan tinggi pada masa pandemi Covid-19. Untuk situasi sekarang ini PPKM level 4 pendapatan makin anjlok, dan hal tersebut tidak hanya berdampak pada Wisata Alam Datuk saja tetapi semua wisata yang ada di Kabupaten Batu Bara. Pada situasi PPKM level 4 tidak ada kunjungan dari wisatawan luar kota, yang berkunjung hanya wisatawan dalam kota itupun sangat menurun drastis".

Pandemi Covid-19 juga berdampak bagi para pedagang yang berjualan di Wisata Alam Datuk. Berdasarkan hasil wawancara dengan beberapa pedagang yang ada disana, pendapatan mereka pada awal pandemi Covid-19 benar-benar anjlok, bahkan sama sekali tidak memiliki pendapatan karena penutupan tempat wisata yang dilakukan oleh pemerintah. Hal tersebut menyebabkan mereka memutar otak untuk berdagang dirumah agar tetap mendapatkan penghasilan. Pada masa new normal Wisata Alam Datuk kembali dibuka dan mereka kembali berdagang, tetapi pendapatan tidak seperti sebelum masa pandemi Covid-19 dikarenakan jumlah pengunjung Wisata Alam Datuk yang berkurang. 
P-ISSN 2580 - 7781

E-ISSN 2615 - 3238

\section{KESIMPULAN}

Wabah Covid-19 membuat lemahnya berbagai aktivitas di kehidupan manusia. Dampak Covid-19 sangat berpengaruh besar dalam berbagai sektor. Terlebih lagi dalam sektor perekonomian diberbagai daerah dan kawasan wisata. Diantara kawasan wisata yang merasakan dampak pandemi Covid-19 di Indonesia adalah di Wisata Alam Datuk, Desa Kuala Indah, Kabupaten Batubara, yang sejak lama memiliki daya tarik tersendiri dalam menarik wisatawan. Terlebih pada aktivitas lintas sektor pariwisata juga berdampak pada lintas pelaku ekonomi. Seperti berdagang di lokasi wisata yang dalam hal ini seharusnya dapat membantu kegiatan ekonomi masyarakat Kuala Indah melalui sektor pariwisatanya. Namun para pedagang pun diharuskan untuk menutup usahanya dan pengelola pariwisata mengubah skema gaji para karyawannya dalam masa pandemi ini. Melihat peluang dari berbagai sektor khususnya sektor pariwisata yang berkontribusi besar dalam ekonomi masyarakat. Pengembangan pariwisata ini diharapkan dapat menstabilkan kembali keadaan ekonomi. Hal ini menjadi tantangan bagi pemerintahan Desa Kuala Indah untuk menggerakkan kembali aktivitas roda perekonomian yang sedang melemah. Dengan mengeluarkan beberapa kebijakan dari pemerintah seperti new normal dan kebijakan lainnya yang akan diterapkan dan diharapkan dapat menstabilkan keadaan ekonomi kembali.

\section{DAFTAR PUSTAKA}

Abbas, E. W., Handy, M. R. N., Shaleh, R. M., \& Hadi, N.T.F.W. 2020. Ecotourism of Martapura River Banjarmasin as a Learning Resources on Social Studies. The Innovation of Social Studies Journal, 1(2): 11-119.

Isbaniah, Fathiyah, et.al. 2020. Pedoman Pencegahan dan Penanggulangan Covid 19. Jakarta: Direktorat Jenderal Pencegahan dan Pengendalian Penyakit Kemenkes.

Maulidiyah, M., Subiyakto, B., \& Hasanah, M. 2020. Economic Activities in The Kebun Rambutan Rakyat Sungai Lulut as a Learning Resource on Social Studies. The Kalimantan Social Studies Journal, 1(2):175-183.

Purwahita, A.A.A, Ribeka, Martha, et.al. 2021. Dampak Covid-19 Terhadap Pariwisata Bali Ditinjau Dari Sektor Sosial, Ekonomi, Dan Lingkungan (Suatu Tinjauan Pustaka), Jurnal Kajian dan Terapan Pariwisata, 1(2): 68-80. 
P-ISSN 2580 - 7781

E-ISSN $2615-3238$

Sholahuddin, M. 2007. Asas-Asas Ekonomi Islam. Jakarta: PT. Raja Grafindo Persada.

Susilo, Adityo, et.al. 2020. Coronavirus Disease 2019: Tinjauan Terkini, Universitas Indonesia. [Online]. Tersedia pada: http://jurnalpenyakitdalam.ui.ac.id/index.php/jpdi/article/view/415/228

Syaharuddin, S. 2020. Menimbang Peran Teknologi dan Guru dalam Pembelajaran di Era COVID-19.

Yuniarti, D., Subiyakto, B., \& Putra, M. A. H. 2020. Economic Activities in Kuin Floating Market as a Learning Resource on Social Studies. The Kalimantan Social Studies Journal, 1(2):130-140. 